\title{
STRATEGI DINAS PERINDUSTRIAN, PERDAGANGAN DAN KOPERASI (PERINDAGKOP) KABUPATEN NAGAN RAYA DALAM MENGEMBANGKAN USAHA KECIL DAN MENENGAH
}

\author{
Adam Sani \\ Fakultas Ilmu Sosial dan Ilmu Politik Universitas Teuku Umar \\ Adam_beutong87@yahoo.com
}

\begin{abstract}
The purpose of this research is to know the strategy of Industry, Trade and Cooperative Office in developing small and medium enterprises in Nagan Raya District and to know the obstacles faced by Industry, Trade and Cooperative Office in developing small and medium enterprises in Nagan Raya District. The method used in this research is descriptive qualitative with the source data taken through observation, interview and documentation. Disperindagkop Nagan Raya District in the development of Small and Medium Enterprises namely guidance and Counseling, covering (a) the development of various products, (b) improvement of product quality, (c) licensing counseling, (d) marketing, education and training, covering (a) management Capital and finance, (b) production techniques, (c) entrepreneurship, Provision of Assistance, covering (a) capital assistance, (b) equipment aid and Evaluation and supervision. There are also inhibiting factors, such as internal resistor factors from Disperindagkop Nagan Raya District that is the level of quality and quantity of apparatus is still limited, the amount of budget funds for UKM development program. And supporting facilities and infrastructure are still inadequate. External inhibiting factors are the level of quality of human resources is still limited, lack of interest in trying. The authors provide suggestions that can be utilized by relevant agencies Increasing the frequency of meetings with UKM and the growing interest of young people to the importance of wrestle in the field of business.
\end{abstract}

Keywords: Strategy, Development, UKM, Disperindagkop. 


\section{PENDAHULUAN}

Penyelenggaraan pemerintahan daerah sesuai dengan amanat Undang-Undang Dasar Negara Republik Indonesia Tahun 1945, menuntut pemerintah daerah untuk dapat mengatur serta mengurus sendiri urusan pemerintahan masing-masing menurut asas otonomi dan tugas pembantuan. Selain itu, pemerintah daerah diarahkan untuk dapat mempercepat terwujudnya kesejahteraan masyarakat melalui peningkatan, pelayanan, pemberdayaan dan peran serta masyarakat, serta peningkatan daya saing daerah, dengan memperhatikan prinsip demokrasi, pemerataan, keadilan, keistimewaan, dan kekhususan suatu daerah dalam sistem Negara Kesatuan Republik Indonesia. Penyelenggaraan pemerintahan daerah ini dilaksanakan dengan lebih memperhatikan aspek-aspek hubungan antar susunan pemerintahan dan antar pemerintahan daerah, potensi dan keanekaragaman daerah, peluang dan tantangan persaingan global dengan memberikan kewenangan yang seluas-luasnya kepada daerah disertai dengan pemberian hak dan kewajiban menyelenggarakan otonomi daerah dalam kesatuan sistem penyelenggaraan pemerintahan negara. Sebagai konsekuensi dari adanya kebijakan otonomi daerah tersebut, maka pemerintah telah mengeluarkan Undang-Undang No. 32 Tahun 2004 tentang Pemerintah Daerah yang membawa perubahan besar terhadap sistem pemerintahan di Indonesia. Dengan adanya Undang-Undang tersebut, maka dapat dilihat bahwa adanya landasan hukum yang kuat bagi penyelenggaraan otonomi daerah, dengan memberikan keleluasaan kepada daerah untuk mewujudkan daerah yang mandiri dalam kerangka kesatuan dan persatuan bangsa sesuai dengan UUD 1945. Selain itu, konsekuensi dari adanya kebijakan otonomi daerah tersebut adalah adanya upaya pemberdayaan dan peningkatan perekonomian daerah melalui perimbangan keuangan yang baik antara pemerintah pusat dan pemerintahan daerah.

Sesuai dengan pasal 33 ayat 1 UUD 1945 bahwa Perekonomian disusun sebagai usaha bersama berdasar atas asas kekeluargaan. Hal ini lebih ditegaskan lagi dalam penjelasan pasal 33 tersebut bahwa kemakmuran masyarakatlah yang diutamakan, bukan kemakmuran orang seorang. Usaha Mikro Kecil dan Menengah (UKM) merupakan representasi rakyat Indonesia dalam kehidupan ekonomi nasional, sehingga perlu diberikan prioritas yang tinggi dalam pembangunan nasional. Untuk itu, perlu disusun strategi pengembangan koperasi dan UKM di Indonesia yang terintegrasi, sistematis, dan berkelanjutan.

Usaha Kecil dan Menengah (UKM) dalam perekonomian nasional memiliki peran yang penting dan strategis. Pertama, karena jumlah industrinya yang besar dan terdapat dalam setiap sektor ekonomi. Kedua, potensinya yang besar dalam penyerapan tenaga kerja. Setiap unit investasi pada sektor UKM dapat menciptakan lebih banyak tenaga kerja jika dibandingkan dengan investasi yang sama pada usaha besar. Ketiga, kontribusi UKM dalam pembentukan PDRB cukup signifikan.

Pada kenyataannya, peran usaha kecil dan menengah (UKM) dalam perekonomian Indonesia belum mampu meningkatkan daya saing ekonomi ditingkat Internasional. Hasil penelitian Word Economic Forum terhadap 59 negara termasuk Indonesia menunjukkan bahwa Indonesia menduduki posisi ke 7 pada tahun 1999. Rendahnya daya saing ekonomi Indonesia disebabkan oleh banyak faktor diantaranya minat dan sumber daya manusia yang masih terbatas. Permasalahan pokok yang sering dihadapi oleh sebagian besar usaha kecil dan menengah antara lain pemasaran, keuangan, manajemen, teknologi, lokasi, sumber daya manusia dan struktur ekonomi.

Pengembangan sektor UKM di Nagan Raya dirasa sangat penting untuk dilakukan. Sebab, dilihat dari kondisi yang ada saat ini, sektor UKM masih kurang memberikan lahan pekerjaan bagi tenaga kerja yang belum tertampung dalam dunia kerja. Selain itu, sektor UKM juga belum maksimal dalam memberikan kontribusi yang signifikan bagi pemasukan PAD (Pendapatan Asli Daerah). Maka dari itu, merupakan tugas utama bagi Dinas Perindustrian, Perdagangan dan Koperasi untuk melaksanakan kewenangan otonomi daerah 
dalam melaksanakan tugas desentralisasi dibidang koperasi dan UKM. Sebagai konsekuensinya, hendaknya Dinas Perindustrian, Perdagangan dan Koperasi melakukan berbagai strategi yang tepat serta mengkoordinir setiap hambatan kegiatan untuk mengembangkan potensi sektor usaha kecil dan menengah. Berdasarkan latar belakang tersebutlah tulisan ini mengkaji tentang "Strategi Dinas Perindustrian, Perdagangan dan Koperasi (Disperindagkop) dalam Mengembangkan Usaha Kecil dan Menengah di Kabupaten Nagan Raya“.

\section{KAJIAN LITERATURE Pengertian Strategi}

Kata strategi berasal dari bahasa Yunani "strategos", yang berarti a general set of maneuver carried out to overcome an enemy during combat, yaitu sekumpulan senjata yang digunakan untuk memerangi musuh selama peperangan. Jadi, memang istilah strategi semula bersumber dari kalangan militer dan secara popular sering dinyatakan sebagai "kiat yang digunakan oleh para jenderal untuk memenangkan suatu peperangan". Namun dewasa ini istilah strategi sudah digunakan oleh semua jenis organisasi, dan ide-ide pokok yang terdapat dalam pengertian semula tetap dipertahankan, hanya saja aplikasinya disesuaikan dengan jenis organisasi yang menerapkannya. Menurut Nawawi, 2000 Secara umum strategi diartikan sebagai suatu cara yang digunakan oleh manajer atau pimpinan puncak untuk mencapai tujuan organisasi. Strategi merupakan landasan awal bagi sebuah organisasi dan elemen-elemen di dalamnya untuk menyusun langkah-langkah atau tindakan-tindakan dengan memperhitungkan faktor-faktor internal dan eksternal dalam rangka pencapaian tujuan yang telah ditentukan.

Bryson dalam bukunya "Perencanaan Strategik Untuk Organisasi Sosial" memberikan definisi strategi sebagai pola tujuan, kebijakan, program, tindakan, keputusan, atau alokasi sumber daya yang mendefinisikan bagaimana organisasi itu, apa yang dikerjakan organisasi, dan mengapa organisasi harus mengerjakannya (Jhon, M. 2005).

Sesuai perkembangannya definisi strategi mengalami perluasan arti. Berikut ini beberapa definisi yang diberikan oleh beberapa ahli manajemen. memberikan definisi strategi sebagai berikut strategi merupakan respon secara terus menerus maupun adaptif terhadap peluang dan ancaman eksternal serta kekuatan dan kelemahan internal yang dapat mempengaruhi organisasi (Rangkuti, 2002). Dari pendapat tersebut dapat disimpulkan bahwa strategi adalah pola tujuan, kebijakan, program, tindakan, keputusan, dan alokasi sumber daya organisasi untuk mencapai sasarannya melalui hubungan yang efektif dengan lingkungan dalam kondisi yang paling menguntungkan.

\section{Pengembangan Usaha Kecil dan Menengah}

Kata "pengembangan" yang dikemukakan oleh J. S. Badudu dikutip dari KBBI, yaitu : Sebagaimana tercantum dalam Kamus Umum Bahasa Indonesia mengandung arti sebagai hal, cara, atau hasil mengembangkan; sedangkan mengembangkan sendiri berarti membuka, memajukan, menjadi maju, dan bertambah baik. Definisi lain mengenai pengembangan menurut Kamus Besar Bahasa Indonesia adalah sebagai berikutPengembangan merupakan proses, cara, perbuatan mengembangkan, sedangkan mengembangkan merupakan perintah selalu berusaha di pembangunan secara bertahap dan teratur yang menjurus pada sasaran yang dikehendaki (Badudu, 1989). Dari definisi tersebut, dapat diketahui bahwa pengembangan merupakan suatu upaya untuk meningkatkan segala aspek dalam tubuh organisasi agar mengarah pada pencapaian tujuan.

Adapun pendapat Amin Widjaja Tunggal yang dikutip dari Wijayanti mengenai pengembangan yaitu bahwa pengembangan merupakan suatu usaha yang dilakukan organisasi untuk memperbaiki pelaksanaan pekerjaan yang mengacu pada kemampuan meningkatkan daya tanggap organisasi terhadap perubahan lingkungan untuk mencapai efisiensi dan efektivitas (Wijayanti, 2002) 
Undang-Undang Nomor 20 Tahun 2008 tentang Usaha Mikro Kecil dan Menengah menjelaskan bahwa hakikat dari pengembangan adalah upaya yang dilakukan oleh Pemerintah, Pemerintah Daerah, Dunia Usaha, dan masyarakat untuk memberdayakan Usaha Mikro, Kecil, dan Menengah melalui pemberian fasilitas bimbingan pendampingan dan bantuan perkuatan untuk menumbuhkan dan meningkatkan kemampuan dan daya saing Usaha Mikro, Kecil, dan Menengah (UU No 20 Tahun 2008.

\section{Usaha Kecil dan Menengah}

Undang-Undang Nomor 20 Tahun 2008 Tentang Usaha Kecil, Mikro dan Menengah menjelaskan beberapa kriteria mengenai Usaha Mikro, Kecil, dan Menengah. Kriteria-kriteria tersebut antara lain sebagai berikut:

a. Kriteria Usaha Mikro adalah sebagai berikut:

1. Memiliki kekayaan bersih paling banyak Rp 50.000.000,00 (lima puluh juta rupiah) tidak termasuk tanah dan bangunan tempat usaha; atau

2. Memiliki hasil penjualan tahunan paling banyak Rp 300.000.000,00 (tiga ratus juta rupiah).

b. Kriteria Usaha Kecil adalah sebagai berikut:

1. Memiliki kekayaan bersih lebih dari Rp 50.000.000,00 (lima puluh juta rupiah) sampai dengan paling banyak Rp 500.000.000,00 (lima ratus juta rupiah) tidak termasuk tanah dan bangunan tempat usaha; atau

2. Memiliki hasil penjualan tahunan lebih dari $\mathrm{Rp} 300.000 .000,00$ (tiga ratus juta rupiah) sampai dengan paling banyak Rp 2.500.000.000,00 (dua milyar lima ratus juta rupiah)

c. Kriteria Usaha Menengah adalah sebagai berikut:

1. Memiliki kekayaan bersih lebih dari Rp 500.000.000,00 (lima ratus juta rupiah) sampai dengan paling banyak Rp 10.000.000.000,00 (sepuluh milyar rupiah) tidak termasuk tanah dan bangunan tempat usaha; atau

2. Memiliki hasil penjualan tahunan lebih dari Rp 2.500.000.000,00 (dua milyar lima ratus juta rupiah) sampai dengan paling banyak Rp 50.000.000.000,00 (lima puluh milyar rupiah).

Jika pada Undang-Undang tersebut lebih menekankan pada aspek keuangannya saja, maka berbeda dengan definisi Usaha Mikro, Kecil, dan Menengah yang tercantum pada Rencana Strategis Kementrian Koperasi dan UKM, yang lebih mendefinisikan UKM dari berbagai aspek, antara lain :

1. Usaha Mikro adalah kegiatan ekonomi rakyat berskala kecil dan bersifat tradisional dan informal, dalam arti belum terdaftar, belum tercatat, dan belum berbadan hukum, dengan hasil penjualan tahunan paling banyak $\mathrm{Rp}$ 100.000.000,00 (seratus juta rupiah) atau kekayaan bersih paling banyak Rp 50.000.000 (lima puluh juta rupiah).

2. Usaha Kecil adalah kegiatan ekonomi rakyat yang memenuhi kriteria sebagai berikut : Memiliki kekayaan bersih paling banyak Rp 200.000.000,00 (dua ratus juta rupiah). tidak termasuk tanah dan bangunan tempat usaha; atau memiliki hasil penjualan tahunan paling banyak Rp 1.000.000.000,00 (satu milyar rupiah); Milik Warga Negara Indonesia; Berdiri sendiri, bukan merupakan anak perusahaan atau cabang perusahaan yang dimiliki, dikuasai, atau berafiliasi baik langsung maupun tidak langsung dengan usaha menengah atau usaha besar; Berbentuk usaha orang perseorangan, badan usaha yang tidak berbadan hukum, atau badan usaha yang berbadan hukum, termasuk koperasi.

Meskipun terdapat banyak definisi mengenai Usaha Mikro, Kecil, dan Menengah, namun secara umum UKM dilihat dari ciri-cirinya pada dasarnya bisa dianggap sama, yaitu sebagai berikut Struktur organisasi yang sangat sederhana, tanpa staf yang berlebihan,pembagian kerja yang kendur, memiliki hirarki manajerial yang pendek, ktifitas 
sedikit yang formal, dan sedikit menggunakan proses perencanaan dan kurang membedakan asset pribadi dari asset perusahaan (Ayu, 2007.

Dari asas tersebut disimpulkan bahwa Usaha Kecil dan Menengah bertujuan menumbuhkan dan mengembangkan usahan dalam rangka membangun perekonomian nasional berdasarkan demokrasi ekonomi yang berkeadilan.

\section{METODOLOGI PENELITIAN}

Metode penelitian adalah cara yang digunakan untuk penelitian tertentu sesuai dengan tujuan yang ingin dicapai. Penelitian ini menggunakan jenis penelitian deskriptif kualitatif. Penelitian deskriptif bertujuan untuk menggambarkan secara tepat fenomena yang terjadi secara sistematis, aktual, dan akurat sesuai dengan fakta yang ada dengan mengumpulkan data, menjelaskan dan melakukan analisa secara obyektif dalam arti hasil penelitian ini akan lebih menekankan pada gambaran mengenai obyek penelitian yang sebenarnya (Moleong, 2007).

Penelitian ini dilakukan melalui penelitian kualitatif dengan menggunakan metode deskriptif analisis dimaksudkan untuk menyusun gambaran mengenai obyek yang diteliti dengan terlebih dahulu peneliti mengumpulkan data-data di lokasi penelitian, lalu data tersebut diolah dan diartikan untuk kemudian dapat melakukan analisa dan interpretasi dari data yang telah disajikan.

Pada pendekatan kualitatif pada penelitian ini peneliti membuat suatu gambaran kompleks, meneliti kata-kata, laporan terinci dari pandangan responden, dan melakukan studi dapat situasi yang alami. Metodologi kualitatif merupakan prosedur penelitian yang menghasilkan data deskriptif berupa kata-kata tertulis maupun lisan Bicara orang-orang yang diamati.

\section{Sumber Data}

Dalam penelitian ini, sumber data dibedakan ke dalam dua bagian yaitu sumber data primer dan sumber data sekunder:

a. Sumber data primer

Sumber data utama atau pokok yang dijadikan bahan penelitian dan analisis. Dalam penelitian ini penulis memperoleh sumber data primer dari hasil dari observasi, wawancara dan dokumentasi. Informasi untuk memperoleh data primer dalam penelitian ini adalah pihak-pihak yang terkait dengan proses pelaksanaan kegiatan pengembangan UKM yang dilakukan oleh Dinas Perindustrian, Perdagangan dan Koperasi Kabupaten (Disperindagkop) Kabupaten Nagan Raya. Adapun jumlah responden tersebut adalah 13 orang yaitu kepala Dinas, Sekretaris Dinas, Kepala Bidang Industri dan Kepala Bidang UKM masing masing 1 orang, Staf Bidang UKM 4 orang dan pelaku UKM binaan sebanyak 5 orang.

b. Sumber data sekunder

Sumber data yang menjadi bahan penunjang dan pelengkap dalam melakukan penelitian. Data tersebut berkenaan bahan bacaan seperti buku-buku, artikel, kamus, surat kabar, majalah, prasasti, notulen rapat, agenda, dan sebagainya.

\section{Teknik pengumpulan data}

Teknik pengumpulan data merupakan suatu langkah yang harus digunakan dalam mengadakan suatu penelitian, agar mendapat data sesuai dengan apa yang diinginkan. Teknik pengumpulan data yang digunakan dalam penelitian ini melalui Observasi, Wawancara dan dokumentasi. 


\section{Teknik Analisis Data}

Analisa data yang digunakan dalam penelitian yaitu:

a. Data Reduction

Mereduksi data adalah proses mempertegas, memperpendek, menyeleksi, membuat fokus, membuang yang tidak penting, dan mengatur data sedemikian rupa sehingga kesimpulan akhir dapat ditemukan.

b. Data Display

Merupakan kegiatan pengorganisasian data, agar tersusun dalam pola hubungan, sehingga akan makin mudah dipahami. Dengan mendisplaykan data, maka akan memudahkan untuk memahami apa yang terjadi dan merencanakan kerja.

c. Conclusion Drawing

Dalam awal pencarian data, peneliti harus sudah mengerti apa arti hal-hal yang ia temui dengan melakukan pencatatan peraturan, pola-pola, pernyataan-pernyataan, konfigurasikonfigurasi yang mungkin, arahan sebab akibat, dan proposisi-proposisi. Berbagai hal tersebut dipegang oleh peneliti tidak secara kuat, tetap bersikap terbuka, awalnya kurang jelas, kemudian semakin meningkat secara eksplisit hingga memiliki landasan yang kuat.

\section{Jadwal Penelitian}

Penelitian ini dilaksanakan pada bulan februari 2017 di Dinas Perindustrian, perdagangan dan Koperasi kabupaten Nagan Raya.

\section{HASIL PENELITIAN DAN PEMBAHASAN}

Dinas Perindustrian, Perdagangan dan Koperasi (Disperindagkop) Kabupaten Nagan Raya dibentuk dengan Keputusan Bupati Nagan Raya Nomor. 5 Tahun 2001 tentang pembentukan Susunan Organisasi Dinas-Dinas Kabupaten Nagan Raya. Dinas Perindustrian, Perdagangan dan Koperasi (Disperindagkop) Kabupaten Nagan Raya adalah unsur pelaksana Pemerintah Kabupaten Nagan Raya yang berada di bawah dan bertanggungjawab kepada Bupati melalui Sekretaris Daerah, dengan dipimpin oleh seorang Kepala Dinas.

Dinas Perindustrian, Perdagangan dan Koperasi Kabupaten Nagan Raya memiliki tugas membantu Bupati dalam melaksanakan kewenangan pemerintah kabupaten di bidang Perindustrian, Perdagangan, Koperasi berdasarkan azas otonomi dan tugas pembantuan. Dalam menyelenggarakan tugas sebagaimana dimaksud, Disperindagkop Kabupaten Nagan Raya mempunyai fungsi :

a. perumusan kebijakan teknis penyelenggaraan Pemerintah Daerah di bidang Perindustrian, Perdagangan, Koperasi dan Usaha Mikro, Kecil dan Menengah yang meliputi perindustrian, perdagangan, koperasi, usaha mikro, kecil dan menengah dan pengelolaan pasar serta Kesekretariatan.

b. penyelenggaraan urusan pemerintahan dan pelaksanaan pelayanan umum dibidang perindustrian, perdagangan, Koperasi dan Usaha Mikro, Kecil dan Menengah, dan Pengelolaan Pasar serta kesekretariatan.

c. pembinaan dan Pelaksanaan tugas di bidang Perindustrian, Perdagangan, Koperasi dan Usaha Mikro, Kecil dan Menengah yang meliputi Perindustrian, Perdagangan, Koperasi, Usaha Mikro, Kecil dan Menengah dan Pengelolaan Pasar serta Kesekretariatan.

d. pembinaan terhadap Unit Pelaksana Teknis dalam lingkup Dinas Perindustrian, Perdagangan, koperasi, Usaha Mikro, Kecil dan Menengah.

e. pelaksanaan tugas lain yang diberikan oleh Bupati sesuai dengan tugas dan fungsinya. 


\section{Deskripsi Usaha Kecil dan Menegah Kabupaten Nagan Raya}

Menurut sumber data yang diambil dari Dinas Perindustrian, Perdagangan dan Koperasi Kabupaten Nagan Raya jumlah UKM secara keseluruhan berdasarkan perkecamatan adalah sebagai berikut :

Tabel 1.1. Jumlah UKM secara keseluruhan berdasarkan perkecamatan

\begin{tabular}{|l|l|c|c|c|}
\hline No & \multicolumn{1}{|c|}{ Kecamatan } & Kecil & Menengah & Jumlah \\
\hline 1 & Beutong & 43 & 0 & 43 \\
\hline 2 & Beutong Ateuh Banggalang & 0 & 0 & 0 \\
\hline 3 & Darul Makmur & 196 & 5 & 201 \\
\hline 4 & Tadu Raya & 32 & 0 & 32 \\
\hline 5 & Tripa Makmur & 19 & 0 & 19 \\
\hline 6 & Seunagan & 146 & 0 & 146 \\
\hline 7 & Kuala Pesisir & 41 & 0 & 41 \\
\hline 8 & Kuala & 76 & 9 & 638 \\
\hline 9 & Seunagan Timur & 63 & 1 & 77 \\
\hline 10 & Suka Makmue & $\mathbf{1 . 2 4 5}$ & $\mathbf{1 6}$ & $\mathbf{1 2 6 1}$ \\
\hline & Jumlah Total & & \\
\hline
\end{tabular}

Sumber: Disperindagkop Kab. Nagan Raya Tahun 2016

Dari total jumlah Usaha Kecil dan Menengah di Kabupaten Nagan Raya tersebut tersebut hanya 791 Unit yang mendapat pembinaan. Jumlah tersebut dapat dilihat pada tabel berikut ini: Tabel 1.2. Jumlah UKM Binaan Dinas Perindustrian, Perdagangan dan Koperasi Kab. Nagan Raya

\begin{tabular}{|c|c|c|l|}
\hline No & Sektor & Jumlah Unit & \multicolumn{1}{|c|}{ Tempat } \\
\hline 1 & Pertambangan & 1 Unit & Kec. Kuala \\
\hline 2 & Industri & 146 Unit & Seluruh kecamatan \\
\hline 3 & Pertanian & 1 Unit & Kec. Beutong \\
\hline 4 & Perdagangan & 635 Unit & Seluruh kecamatan \\
\hline 5 & Perikanan & 2 Unit & Kec. Beutong dan Seunagan Timur \\
\hline 6 & Transportasi & 2 Unit & Kec. Seunagan dan Kuala \\
\hline 7 & Peternakan & 4 Unit & $\begin{array}{l}\text { Kec. Darul Makmur dan, Suka Makmue } \\
\text { dan Seunagan Timur }\end{array}$ \\
\hline \multicolumn{2}{|c|}{ Total } & $\mathbf{7 9 1}$ unit & \multicolumn{1}{l}{} \\
\hline
\end{tabular}

Sumber : Disperindagkop Kab. Nagan Raya Tahun 2016

Berdasarkan tabel 1.1 dan 1.2 diatas maka dapat disimpulkan bahwa di Kabupaten Nagan Raya terdapat 1.261 unit usaha kecil dan menengah. Dari jumlah tersebut hanya terdapat 791 unit yang dibina sedangkan sisanya yang berjumlah 470 unit UKM belum mendapat pembinaan oleh Dinas Perindustrian, Perdagangan dan Koperasi Kabupaten Nagan Raya.

Mengenai perbedaan perkembangan usaha kecil dan menengah di Kabupaten Nagan Raya sebelum dan setelah mendapat pembinaan sangat signifikan. bahwa perbedaan antara UKM yang mendapat pembinaan dengan yang tidak sangat jelas terlihat, khususnya hasil usaha yang didapat melalui usaha masyarakat tersebut. UKM yang dibina justru akan mendapat hasil yang meningkat dibandingkan UKM yang tidak dibina dan Disperindagkop terus melakukan pembinaan sampai selesai.

Strategi Dinas Perindustrian, Perdagangan dan Koperasi (Disperindagkop) Kabupaten Nagan Raya dalam Mengembangkan Usaha Kecil dan Menengah

Strategi pengembangan UKM merupakan upaya yang dilakukan oleh pemerintah, dunia usaha dan masyarakat melalui pembinaan dan pemberian bantuan penguatan untuk menumbuhkan dan meningkatkan usaha agar menjadi industri yang tangguh dan mandiri. 
Selanjutnya, fokus penelitian mengenai strategi pengembangan UKM akan mengacu pada siapa pelaksana strategi, bentuk strategi apa yang digunakan, tahapan strategi, dan bagaimana implementasi strateginya, serta faktor pendukung dan faktor penghambat strategi. Sehingga pelaksanaannya dapat diketahui secara pasti. Bentuk Strategi yang menjadi acuan dalam pengembangan UKM di Kabupaten Nagan Raya tersebut akan dijelaskan lebih lanjut sebagai berikut:

\section{a. Bimbingan dan Penyuluhan}

Dalam kegiatan bimbingan dan penyuluhan ini diberikan berbagai materi seputar pengembangan UKM. Materi yang diberikan oleh aparat Disperindagkop Kabupaten Nagan Raya adalah sebagai berikut :

1). Pengembangan Ragam Produk.

Dalam mengembangkan produknya kebanyakan pengusaha kecil tidak berupaya untuk melalukan perubahan dan penambahan produk agar lebih beragam. Hal ini dikarenakan para pengusaha kecil takut produk barunya tidak laku di pasar. Namun yang terjadi di lapangan sebaliknya, konsumen atau masyarakat kadang merasa bosan terhadap produk yang tidak pernah berubah.

2). Peningkatan Kualitas Produk.

Untuk peningkatan kualitas produk ini biasanya aparat Disperindagkop Kabupaten Nagan Raya memberikan masukan kepada pengusaha kecil tentang cara pemilihan bahan baku dan pemrosesan yang baik dan benar. Hal ini dikarenakan terkadang para pengusaha mengabaikan kualitas bahan, karena harga yang lebih mahal dan juga proses yang memerlukan waktu dan perhatian lebih. Pada akhirnya berpengaruh terhadap produk yang dihasilkan kurang diterima masyarakat. Aparat Disperindangkop Kabupaten Nagan Raya memberikan contoh bahan baku yang bermutu baik dan cara pemrosesan, sehingga bahan baku menjadi lebih berkualitas, yakni dengan menggunakan bahan baku yang tidak cacat.

3). Penyuluhan Perijinan

Untuk menjamin kepastian usahanya, para pengusaha kecil diberikan penyuluhan mengenai pentingnya kelengkapan perijinan usaha terutama Surat Ijin Usaha Perdagangan (SIUP), Tanda Daftar Industri (TDI), dan Nomor Pajak Wajib Pajak (NPWP). Penyuluhan yang diberikan Disperindangkop Kabupaten Nagan Raya berupa pentingnya memliki surat-surat tersebut dan juga prosedur untuk memilikinya. Berikut adalah manfaat dari surat-surat tersebut:

- Mendapatkan jaminan perlindungan hukum demi kelangsungan dan kepastian usahanya.

- Memiliki salah satu syarat penting untuk mengajukan kredit ke perbankan.

- Mendapatkan pembinaan dan pengarahan dari pemerintah, baik mengenai permodalan maupun manajemen usahanya.

- terlindung dari praktek usaha yang tidak jujur.

Walaupun demikian, industri kecil yang tidak memiliki surat ijin lengkap tetap diperkenankan memperoleh kucuran dana pinjaman. Industri kecil tersebut dapat memperoleh kredit dengan surat keterangan dari pihak kelurahan, selanjutnya mereka akan diarahkan untuk mendapatkan pinjaman yang memiliki persyaratan yang lebih lunak, seperti program pinjaman kredit tanpa angguna dengan plafond maksimal Rp. 5 juta.

4). Pemasaran

Pemasaran merupakan kegiatan terpenting yang dilakukan oleh seorang pengusaha kecil. Keberhasilan dari usahanya sangat tergantung kepada bagaimana seorang pengusaha mampu memasarkan produknya sehingga masyarakat mau membeli produknya. Kegiatan pemasaran dapat dikatakan berhasil apabila dapat diserap oleh pasar. Oleh karena itu, Disperindagkop Kabupaten Nagan Raya berkompeten dalam upaya membantu mempromosikan hasil produksi para pengusaha kecil. Bentuk kegiatan untuk memasarkan produk yang dihasilkan pengusaha kecil adalah berupa pameran-pameran maupun kerjasama lintas daerah. Manfaat yang 
diharapkan dengan mengikuti pameran-pameran itu adalah minimal masyarakat mengetahui produk dari industri kecil tersebut.

Disperindangkop Kabupaten Nagan Raya memberikan kesempatan seluas-luasnya kepada semua pengusaha untuk mengikuti pameran dengan menyewa gerai sendiri. Namun untuk pameran berskala lebih besar yang membutuhkan biaya banyak, biasanya Disperindagkop Kabupaten Nagan Raya akan mengkoordinir pengusaha kecil yang menghasilkan produkproduk unggulan di Kabupaten Nagan Raya.

Selain pameran, untuk menunjang pengembangan dan akses serta pasar Disperindagkop Kabupaten Nagan Raya melakukan kegiatan antara lain:

- Pengembangan jaringan pasar UKM melalui kontak dagang dan temu usaha.

- Promosi dan pameran produk

- Pemetaan pasar produk UKM visualisasi dan publikasi melalui media televisi, media cetak dan radio.

- Optimalisasi dan trading house dan website unggulan daerah. Sosialisasi.

- Bimbingan administrasi UKM untuk meningkatkan ketrampilan pengelolaan usaha.

- Pembinaan industri atau pedagang kaki lima

- Peningkatan mutu produk dan penguatan sarana industri kecil.

\section{b. Pendidikan dan Pelatihan}

Pendidikan dan pelatihan merupakan kegiatan dimana Disperindagkop Kabupaten Nagan Raya memberikan bantuan berupa pengetahuan dan ketrampilan berwirausaha kepada pengusaha kecil dan menegah dalam mendirikan, mengelola, mengembangkan dan melembagakan usahanya. Pendidikan dan pelatihan yang diberikan berupa pendidikan dan pelatihan secara teknis yang bertujuan untuk menambah ketrampilan berwirausaha, serta pelatihan manajerial yang bertujuan untuk menambah pengetahuan dan meningkatkan juga memperbaiki kemampuan manajerial dari pengusaha kecil.

Dalam kegiatan pendidikan dan pelatihan Disperindagkop Kabupaten Nagan Raya akan menunjuk dan mengundang para pengusaha, juga oleh permintaan dari pengusaha kecil itu sendiri. Pelatihan ini dilakukan di gampong-gampong, aula kantor Disperindagkop Kabupaten Nagan Raya, atau menyewa tempat untuk mengadakan pelatihan. Untuk waktu kegiatan pelatihan ini adalah tidak terjadwal, hal ini disesuaikan dengan kebutuhan program yang akan disosialisasikan dan anggaran dana yang ada. Adapun materi yang disampaikan dalam kegiatan ini meliputi:

1). Manajemen Permodalan dan Keuangan

Masalah permodalan merupakan masalah yang mendasar bagi pengusaha kecil dalam mengembangkan usahanya. Dalam pendidikan dan pelatihan dijelaskan tentang bagaimana cara mendapatkan pinjaman modal dam prosedur yang harus dilakukan.

2). Teknik Produksi

Dalam materi teknik produksi ini dijelaskan tentang pengembangan metode produksi, inovasi produk, penggunaan teknologi atau peralatan baru dan lainnya. Seperti pelatihan komputerisasi, dimana Disperindagkop Kabupaten Nagan Raya mengajak pengusaha kecil untuk belajar menggunakan komputer, yang bertujuan untuk menunjang kegiatan promosi dan pengembangan usaha mereka. Hal ini dikarenakan selama ini pengusaha kecil termasuk juga pengusaha batik tulis masih menggunakan teknologi yang terbatas dan sederhana dalam berproduksi. Untuk itu Disperindagkop Kabupaten Nagan Raya mengenalkan teknologi baru yang mampu mendukung pengusaha kecil dan menengah.

3). Kewirausahaan.

Dalam hal ini pelatihan-pelatihan mengenai pengetahuan dan keterampilan yang diperlukan untuk berusaha teramat penting. Namun, bersamaan dengan atau dalam pelatihan itu penting pula ditanamkan semangat wirausaha. Bahkan hal ini harus diperluas dan dimulai sejak 
dini, dalam sistem pendidikan kita, dalam rangka membangun bangsa Indonesia yang mandiri, yakni bangsa niaga yang maju dan bangsa industri yang tangguh. Upaya ini akan memperkuat proses transformasi ekonomi yang sedang berlangsung karena didorong oleh transformasi budaya, yakni modernisasi sistem nilai dalam masyarakat.

\section{c. Pemberian Bantuan}

Pemberian bantuan yang dilakukan oleh Disperindagkop Kabupaten Nagan Raya adalah:

1). Bantuan Permodalan

Terbatasnya modal merupakan masalah yang mendasar bagi setiap pengusaha kecil, tidak terkecuali bagi para pengusaha kecil batik tulis dalam mengembangkan usahanya. Hal inilah yang kemudian membuat Disperindagkop Kabupaten Nagan Raya merasa perlu untuk memudahkan pengusaha kecil tersebut dalam memperoleh modal. Fasilitas permodalan yang dimaksud adalah bersumber dari Pemerintah Daerah Kabupaten Nagan Raya melalui Disperindagkop Kabupaten Nagan Raya, selain itu bantuan permodalan juga berasal dari pihak lain yaitu BUMN.

Disperindagkop Kabupaten Nagan Raya mengadakan program perkuatan modal merupakan pinjaman yang bersumber dari APBK dengan bunga 10-12 \% per tahun. Tingkat pinjaman masing-masing Rp. 5-50 juta. Sedangkan pinjaman dari BUMN Disperindagkop hanya berperan sebagai mediator antara pengusaha kecil dengan pihak ketiga. Sebagai contoh, pada tahun 2009 Disperindagkop Kabupaten Nagan Raya memberikan bantuan pinjaman modal sebesar Rp. 500 juta yang berasal dari dana APBK kepada 68 pengusaha kecil.

2). Bantuan Peralatan

Untuk bantuan peralatan biasanya dilakukan bersamaan dengan pelaksanaan kegiatan pendidikan dan pelatihan atau melalui penunjukan langsung dan permintaan dari pengusaha kecil.

\section{d. Monitoring dan Evaluasi UKM}

Beberapa trategi yang diimplementasikan oleh Disperindagkop Kabupaten Nagan Raya untuk mengembangkan Usaha Kecil dan Menengah yakni melalui bimbingan dan penyuluhan, pendidikan dan pelatihan, serta pemberian bantuan, juga melakukan monitoring dan evaluasi serta pelaporan dengan cara mendatangi tempat usaha tersebut untuk dievaluasi lanjutan serta diberikan pembinaan. Dengan begitu akan terlihat apa yang dilakukan oleh Disperindagkop Kabupaten Nagan Raya benar-benar bermanfaat dan dimanfaatkan dengan baik oleh para pengusaha kecil tersebut.

Dari strategi yang telah dilaksanakan oleh Disperindagkop Kabupaten Nagan Raya, juga telah bermanfaat bagi pengusaha kecil dan menengah dalam pengembangan usahanya. Pembinaan permodalan melalui pemberian pinjaman modal dengan bunga lunak kepada pengusaha dari Disperindagkop Kabupaten Nagan Raya yang disalurkan melalui koperasi dan lembaga keuangan lainnya dapat meningkatkan jumlah modal guna memperlancar proses produksi bagi pengusaha kecil dan menengah di Kabupaten Nagan Raya.

\section{Faktor Pendukung dan Faktor Penghambat dalam Pengembangan Usaha Kecil dan Menengah di Kabupaten Nagan Raya}

a. Faktor Pendukung

Salah satu faktor pendukung dalam penerapan strategi pengembangan UKM adalah terjalinnya kerjasama yang baik antara Disperindagkop Kabupaten Nagan Raya, para pengusaha kecil menengah, dan pihak lain yang mendukung. Faktor lainnya adalah semangat dan kemauan dari para pengusaha kecil dan menengah untuk saling bertukar informasi sehingga memudahkan aparat Disperindagkop Kabupaten Nagan Raya dalam menjalankan tugasnya yakni membantu para pengusaha kecil. Hal ini juga yang akhirnya menumbuhkan rasa kekeluargaan diantara 
kedua belah pihak. Kerjasama dari aparat Disperindagkop Kabupaten Nagan Raya yang terbagi dalam 4 bidang, dimana setiap bidang memiliki peran sendiri-sendiri sehingga tidak terjadi lepas tanggungjawab atau tumpang tindih dalam suatu masalah. Bidang Perindustrian yang membidangi teknis produksi, Bidang Perdagangan yang membidangi masalah pemasaran dan, Bidang Koperasi dan UKM yang membidangi masalah permodalan dan kelembagaan.

Selain itu kerjasama yang terjalin dengan instansi-instansi lain yang berkaitan, baik dalam maupun luar daerah juga mendukung dalam penerapan strategi pengembangan UKM ini, yakni (a) lembaga perbankan yang menjelaskan tentang prosedur dan pemberian pinjaman; (b) perusahaan atau instansi yang berperan dalam pemberian bantuan permodalan; (c) Dinas Pariwisata, dalam hal mempromosikan produk unggulan Kabupaten Nagan Raya; (d) Pemerintah Daerah Kabupaten Nagan Raya dan lembaga lainnya yang turut serta membantu dalam pengembangan industri kecil ini.

b. Faktor Penghambat

Selain terdapat faktor yang mendukung Disperindagkop Kabupaten Nagan Raya dalam penerapan strategi pengembangan home industri batik tulis, terdapat 3 faktor yang menghambat dalam penerapan strategi ini, yaitu:

1. Faktor Penghambat Internal

Disperindagkop Kabupaten Nagan Raya sebagai salah satu instansi yang mempunyai wewenang dalam mengembangkan usaha kecil dan menengah diharapkan dapat melaksanakan tugas secara maksimal. Namun dalam pelaksanaannya, Disperindagkop Kabupaten Nagan Raya sendiri mempunyai beberapa kendala, sehingga kurang dapat memaksimalkan program pengembangan UKM. Kendala tersebut antara lain:

a. Tingkat kualitas dan kuantitas SDM aparat masih terbatas.

b. Jumlah anggaran dana untuk program pengembangan UKM terbatas.

c. Sarana dan prasarana penunjang yang masih kurang memadai

\section{Faktor Penghambat Ekternal}

Kendala eksternal berasal dari luar Disperindagkop Kabupaten Nagan Raya, kendala ini datang dari pengusaha atau pelaku UKM maupun keadaan lingkungan secara umum yang mempengaruhi iklim usaha. Kendala tersebut antara lain tingkat kualitas SDM masih terbatas dan minat berusaha masyarakat masih kurang

\section{SIMPULAN DAN SARAN}

\section{A. Simpulan}

Berdasarkan hasil penelitian yang dilakukan dengan menganalisa data-data, keterangan dan penjelasan yang diperoleh, dapat diambil kesimpulan bahwa Disperindagkop Kabupaten Nagan Raya memiliki tugas membantu Bupati dalam melaksanakan kewenangan pemerintah kabupaten di bidang Perindustrian, Perdagangan, Koperasi dan UKM berdasarkan azas otonomi dan tugas pembantuan. Termasuk dalam pengembangan Usaha Kecil dan Menengah.

Sebelum menerapkan strateginya, Disperindagkop Kabupaten Nagan Raya akan mengidentifikasi dan menganalisis UKM, yakni melihat kekuatan maupun kelemahan yang dimiliki oleh UKM tertentu, serta melihat peluang dan ancaman yang akan dihadapi oleh Disperindagkop Kabupaten Nagan Raya. Dalam menjalankan misinya. Sesuai dengan petunjuk dari pemerintah pusat, terdapat strategi yang diterapkan oleh Disperindagkop Kabupaten Nagan Raya dalam pengembangan Usaha kecil dan Menengah meliputi: pertama, Bimbingan dan Penyuluhan, meliputi (a) pengembangan ragam produk, (b) peningkatan kualitas produk, (c) penyuluhan perijinan, (d) pemasaran. Kedua, Pendidikan dan Pelatihan, meliputi (a) manajemen permodalan dan keuangan, (b) teknik produksi, (c) kewirausahaan. Ketiga, Pemberian Bantuan, meliputi (a) bantuan permodalan, (b) bantuan peralatan. Keempat, Evaluasi dan pengawasan. 
Dalam penerapan strategi pengembangan UKM, terdapat faktor pendukung yaitu adanya jalinan kerjasama yang baik antara Disperindagkop Kabupaten Nagan Raya dengan pihak pendukung seperti instansi, lembaga perbankan dan praktisi-praktisi lain yang terkait, serta hubungan yang harmonis dengan pengusaha kecil. Ada pula faktor penghambat, seperti faktor penghambat internal dari Disperindagkop Kabupaten Nagan Raya yaitu tingkat kualitas dan kuantitas aparat masih terbatas, jumlah anggaran dana untuk program pengembangan UKM. Serta sarana dan prasarana penunjang yang masih kurang memadai. Faktor penghambat ekternal yaitu tingkat kualitas sumber daya manusia masih terbatas, kurangnya minat berusaha,

\section{B. Saran}

Dalam kegiatan pengembangan UKM yang dilakukan oleh Disperindagkop Kabupaten Nagan Raya, maka penulis memberikan saran yang dapat dimanfaatkan oleh instansi-instansi terkait:

1. Penambahan frekuensi pertemuan. Dari 10 kali pertemuan dalam 1 bulan yang selama ini dilakukan, dapat ditambahkan menjadi 2-3 kali lipat frekuensi pertemuan antara pengusaha kecil yang ada di Kabupaten Nagan Raya, khususnya pelaku UKM..

2. Diharapkan Disperindagkop Kabupaten Nagan Raya dapat menjalin kerjasama dengan perusahaan-perusahaan besar.

3. Menumbuhkan Minat generasi muda terhadap pentingnya bergelut dibidang usaha.

\section{REFERENSI}

Bryson, John. M. 2005. Perencanaan Strategis Bagi Organisasi Sosial. Yogyakarta: Pustaka Pelajar.

Creswell, Moleong. 2007. Pendekatan Kualitatif dalam penelitian. Yogyakarta: PT Ikada Muda.

Freddy Rangkuty. 2002. Analisis SWOT: Teknik Membedah Kasus Bisnis. Jakarta: Gramedia Pustaka Utama.

Hadari Nawawi. 2000. Manajemen Strategis Organisasi Non Profit Bidang Pemerintahan. Yogyakarta: Gajah Mada University Press.

J.S. Badudu. 1989. Kamus Besar Bahasa Indonesia. Jakarta: Balai Pustaka.

Nurhajati. 2005. Paradigma baru Pengembangan Usaha Kecil Menengah (UKM) untuk Meningkatkan Daya Saing Ekomomi. Unisma. Makasar.

Kingkin C. Ayu. 2007. Peranan Dinas Koperasi dan Usaha Kecil Menengah Kota Salatiga dalam Pemberdayaan UKM Konfeksi Melalui Pemasaran. FISIP UNS. Jakarta.

Tuti Wijayanti. 2002. Rencana Strategis Kantor Pariwisata Kab. Klaten dalam Pengembangan Obyek Wisata Makam Sunan Pandanaran, Jakarta.

Undang-Undang Nomor 20 Tahun 2008 tentang Usaha Mikro Kecil dan Menengah 